\title{
PEMODELAN HASIL PRODUKSI PADI DI PROVINSI SULAWESI TENGAH MENGGUNAKAN FIXED EFFECT MODEL (FEM)
}

\author{
Rice Production Modeling in Central Sulawesi Using Fixed Effect Model \\ Nurul Fiskia Gamayanti ${ }^{1 *}$, Junaidi ${ }^{2}$ \\ 1,2 Prodi Statistika, Fakultas MIPA, Universitas Tadulako \\ Jl. Soekarno Hatta Km 9, Palu, Sulawesi Tengah, 94118, Indonesia \\ Corresponding author email : ${ }^{*}$ nurulfiskia@gmail.com
}

\begin{abstract}
Abstrak
Padi merupakan komoditas pangan utama di Indonesia. Tingkat konsumsi padi mayarakat di Sulawesi Tengah sebesar 111,4 kg perkapita pertahun yang lebih tinggi jika dibandingkan dengan masyarakat Sulawesi Selatan yaitu $106,9 \mathrm{~kg}$ perkapita pertahun. Diperlukan model yang dapat memprediksi hasil produksi padi di Sulawesi tengah untuk menjaga stok kebutuhan pangan masyarakat. Fixed effect Model dapat digunakan untuk melihat faktor apa saja yang dapat mempengaruhi hasil produksi padi di Sulawesi Tengah dengan menggunakan pendekatan data penelitian data panel. Fixed effect Model adalah cara mengestimasi data panel dengan menggunakan variabel dummy untuk memperoleh perbedaan intersep yang diinginkan. Dari hasil penelitian ini diperoleh bahwa faktor yang mempengaruhi hasil produksi padi di Sulawesi tengah adalah luas panen dengan setiap kenaikan luas panen sebesar $1 \%$ akan meningkatkan hasil produksi padi sebesar $0,6764 \%$. Dari hasil analisis diperoleh nilai $\mathrm{R}^{2}$ sebesar $98.15 \%$.
\end{abstract}

Kata Kunci : Produksi Padi, Sulawesi Tengah, Fixed effect Model

\begin{abstract}
Rice is the main food commodity in Indonesia. The level of community rice consumption in Central Sulawesi is $111.4 \mathrm{~kg}$ per capita per year, which is higher than the people in South Sulawesi, which is $106.9 \mathrm{~kg}$ per capita per year. A model is needed that can predict the yield of rice production in Central Sulawesi to maintain the stock of food needs of the community. Fixed effect model can be used to see what factors can affect rice production in Central Sulawesi using a panel data research approach. Fixed effect model is a method of estimating panel data by using dummy variables to obtain the desired intercept difference. From the results of this study, it was found that the factors that affect the yield of rice production in Central Sulawesi are harvested area with every $1 \%$ increase in harvested area will increase rice production by $0.6764 \%$. From the results of the analysis, the value of $R$ squared is $98.15 \%$.
\end{abstract}

Keywords: Rice Production, Central Sulawesi, Fixed effect Model

Article info:

Submitted: $17^{\text {th }}$ April $2021 \quad$ Accepted: $01^{\text {st }}$ June 2021

How to cite this article:

N. F. Gamayanti, and J. Junaidi, "PEMODELAN HASIL PRODUKSI PADI DI PROVINSI SULAWESI TENGAH MENGGUNAKAN FIXED EFFECT MODEL (FEM)”, BAREKENG: J. Il. Mat. \& Ter., vol. 15, no. 02, pp. 347-354, Jun. 2021.

This work is licensed under a Creative Commons Attribution-ShareAlike 4.0 International License. Copyright (C) 2021 Nurul Fiskia Gamayanti, Junaidi 


\section{PENDAHULUAN}

Padi atau dengan nama latin Oryza Sativa merupakan tumbuhan atau tanaman budidaya yang di lestarikan di Indonesia. Budidaya padi akan tertus terjadi sampai kurun waktu yang panjang di Indonesia. Hal ini dikarenakan padi merupakan salah satu makanan pokok masyarakat Indonesia. Data yang diperoleh dari kementrian pertanian menunjukkan sumber utama konsumsi kalori penduduk Indonesia adalah dari kelompok padi-padian mencapai 55-60\% [1]. Pada tahun 2019 rata-rata konsumsi beras perkapita masyarakat Indonesia mencapai 94,9 kg per kapita per tahun [2].

Konsumsi makanan pokok masyarakat Indonesia yang masih sangat tergantung dengan beras mengakibatkan pemerintah harus melakukan cara agar dapat mengontrol ketersedian beras tersebut dengan baik. Hal yang dilakukan pemerintah saat ini adalah melakukan swasembada pangan. Guna mencapai kesuskesan swasembada pangan tersebut pemerintahmendorong petani untuk meningkatkan hasil produksi padi dengan menggunakan inovasi teknologi dan memberikan subsidi pupuk. Hal lain yang dilakukan pemerintah yaitu dengan menggalangkan kampanye kepada masyarakat dengan semboyan "satu hari tanpa beras setiap minggunya". Namun hal ini tetap tidak berdampak besar terhadap ketahanan pangan dikarenakan hasil produksi padi hanya sedikit meningkat setiap tahunnya. Hasil produksi padi tahun 2019 adalah 31,31 juta ton, dan mengalami penururnan sebesar 2,63 juta ton atau 7,75 persen jika dibandingkan dengan tahun 2018[3] .

Konsumsi beras masyarakat di Provinsi Sulawesi Tengah adalah 111,4 kg perkapita per tahun. Hal ini lebih tinggi jika di bandingkan dengan Provinsi yang ada di Sulawesi lainnya seperti Sulawesi Selatan $106,9 \mathrm{~kg}$ perkapita per tahun, Gorontalo 107,9 kg perkapita per tahun, dan Sulawesi Tenggara 105,8 kg perkapita per tahun [4]. Sehingga Provinsi Sulawei Tengah memiliki tugas yang lebih besar untuk menghasilkan produksi padi yang lebih besar di bandingan provinsil di Sulawesi lainnya. Salah satu cara yang dapat dilakukan pemerintah Provinsi Sulawesi tengah untuk meningkatkan hasil produksi padinya adalah dengan cara mengetahui faktor-faktor apa saja yang dapat mempengaruhi hasil produksi padi di provinsi tersebut.

Produksi padi yang tidak menentu setiap tahunnya dapat dipengaruhi oleh bebrapa faktor yaitu luas lahan, jumlah tenaga kerja, jumlah pupuk, jumlah obat-obatan, suhu, curah hujan, dan jumlah varietas yang disebar [5]. Salah satu metode yang dapat digunakan untuk menganalisis faktor yang mempengaruhi hasil produksi padi adalah dengan menggunakan Analisis Regresi Berganda pada penelitian terdahulu mengenai model hasil produksi padi menggunakan fixxed effect model pada 14 negara Afrika Barat di dapatkan hasil bahwa pada taraf 5\% semua variabel yaitu impor Pangan, Lahan pertanian, Konsumsi pupuk dan Inflasi mempengaruhi hasil produksi padi di daerah 14 negara yang ada di Afrika Barat [6]. Pengembangan pemodelan hasil produksi yang dapat digunakan untuk mengetahui hubungan atau pengaruh variabel $\mathrm{X}$ terhadap variabel $\mathrm{Y}$ salah satu caranya yaitu dengan menggunakan Analisis regresi data panel dengan menggunakan Fixed Effect Model [7]. Penelitian terdahulu mengenai faktor-faktor yang mempengaruhi inflasi pada kota metropolitan di Indonesia dengan menggunakan perbandingan beberapa pemodelan data panel dengan menghasilkan model terbaik adalah dengan Fixed Effect Model dimana didapatkan faktor yang mempengaruhi adalah jumlah penduduk miskinan, PDRB, dan tingkat pertumbuhan ekonomi dengan berukurangnya $1 \%$ jumlah penduduk miskin akan meningkatkan jumlah inflasi sebesar 0,159 [8]. Maka Fixed Effect Model dapat dijadikan salah satu metode yang dapat digunakan untuk memprediksi suatu model untuk melihat pengaruh dari variabel independent terhadap faktor dependen untuk data yang terdiri dari data panel.

\section{METODE PENELITIAN}

\subsection{Analisis Regresi Data Panel}

Pengembangan dari metode analisis regresi linier berganda salah satunya adalah analisis regresi data panel. Perbedaannya berada pada jenis data penelitian yang akan digunakan. Data panel merupakan data gabungan yang berasal dari gabungan data yang diamati dari beberapa unit cross section dan diamati dalam beberapa runtun waktu tertentu (time series) [9]. Regresi data panel merupakan analisis yang dapat digunakan untuk memodelkan hubungan variabel dependen dan variabel independen yang bebrbentuk panel data [10]. Regresi data panel memiliki beberapa kelebihan dibandingan regresi berganda yaitu dengan jumlah data lebih banyak akan memberikan hasil informasi yang lebih banyak yang tidak di dapatkan pada 
data cross section atau data time series saja. Data Panel juga memberikan hasil penyelesaian yang lebih baik dalam hasil inferensi pada perubahan yang dinamis dibandingkan data cross section. Serta manfaatmanfaat penggunaan data panel juga dapat mengendalikan heterogenitas dalam efek individu [3].

Keunggulan yang dimiliki oleh data panel jika dibandingkan dengan data cross section dan time series adalah sebagai berikut [11] dapat memberikan keanekaragaman yang tegas dalam pemodelan dengan melibatkan variabel secara spesifik, dapat memberikan informasi yang lebih banyak banyak, dapat mengurangi hubungan antar variabel independen, serta lebih cocok jika digunakan dalam kasus yang dinamis, kelebihan data panel lainnya adalah dapat menghasilkan bias yang minimal, dapat mengukur efek yang tidak dapat dillihat jika menggunakan data time-series dan cross section [12].

\subsection{Fixed Effect Model}

Fixed Effect Model merupakan cara mengestimasi data panel dengan menggunakan variabel dummy untuk memperoleh perbedaan intersep yang diinginkan. Pada Fixed effect Model diasumsikan bahwa intersep antar unit cross section dan intersep antar waktu berbeda sedangkan slope tetap [11]. Oleh karena itu, digunakan variabel dummy untuk menjelaskan perbedaan intersep tersebut [13]. Model estimasi pada Fixed Effect Model adalah Least Square Dummy Variable. Least Square Dummy Variable adalah model regresi yang menggunakan estimasi Ordinary Least Square dengan variabel dummy [14].

Model regresi data panel, dengan mengasumsikan intersep yang berbeda antara unit pengamatan dan antar waktu dengan slope yang tetap sama antar unit pengamatan [15]. Dapat disajikan sebagai berikut:

$$
Y_{i t}=\beta_{0}+\beta_{1} X_{1 i t}+\beta_{2} X_{2 i t}+\ldots+\beta_{k} X_{k i t}+\varepsilon_{i t}
$$

dengan :

$\mathrm{Y}_{\text {it }} \quad$ : Variabel dependen cross section ke-i time series ke- $t$

$X_{k i t} \quad$ : Vairabel independen ke- $k$ untuk cross section ke- $i$ tahun ke- $t$

$\beta_{0} \quad$ : Parameter intersep

$\beta_{k} \quad:$ Koefisien regresi ke- $k$

$\varepsilon_{i t} \quad:$ Error term

dimana :

$k=1,2, \ldots, K$

$i=1,2, \ldots, N$

$t=1,2, \ldots, T$

$K$ : Banyak parameter regresi yang akan ditaksir

$N$ : Banyak unit cross section

$T$ : Banyak data time series

Dengn asumsi bahwa $\varepsilon_{i t} \sim N\left(0, \sigma^{2}\right)$, sehingga model tersebut dapat ditaksir dengan Ordinary Least Square (OLS) dimana $\hat{\beta}=\left(X^{\prime} X\right)^{-1}\left(X^{\prime} Y\right)$ sehingga taksiran yang akan dihasilkan adalah

$$
\hat{\beta}=\left[\begin{array}{llllllllll}
\hat{\beta}_{0} & \hat{\mu}_{2} & \ldots & \hat{\mu}_{N} & \hat{\gamma}_{2} & \ldots & \hat{\gamma}_{T} & \hat{\beta}_{1} & \hat{\beta}_{2} & \hat{\beta}_{3}
\end{array}\right] .
$$

Dengan mengasumsikan intersep yang berbeda antara unit pengamatan dan antar waktu dengan slope yang tetap sama antar unit pengamatan. Sehingga model regresi data panel yang digunakan untuk menaksir produksi padi diwilayah Sulawesi Tengah adalah:

$$
Y_{i t}=\beta_{0 i t}+\beta_{1} X_{1 i t}+\beta_{2} X_{2 i t}+\varepsilon_{i t} ; i=1,2, \ldots, 12 ; t=1,2, \ldots, 6
$$

\subsection{Uji Simultan}

Pengujian secara simultan digunakan untuk melihat bagaimana keberartian Fixed Effect Model jika dilihat secara keseluruhan. Pengujian secara simultan dapat dihitung dengan cara menggunakan uji F. Adapun hipotesis pengujian adalah sebagai berikut:

$\begin{array}{ll}H_{0}: \beta_{1}=\beta_{2}=\beta_{3}=0 & \text { (model tidak berarti) } \\ H_{1}: \text { minimal ada satu } \beta_{k} \neq 0 & \text { (model berarti) }\end{array}$

Statistik Uji: $\quad F=\frac{\left(\hat{\beta}^{\prime} X^{\prime} Y-N T \bar{Y}^{2}\right) /(N+k-1)}{\left(Y^{\prime} Y-\hat{\beta}^{\prime} X^{\prime} Y\right) /(N T-N-k)}$ 
Kriteria uji: Tolak $H_{0}$ jika $F_{\text {hitung }}>F_{\text {tabel }}$, artinya model yang diperoleh berarti secara keseluruhan.

\subsection{Uji Parsial}

Pengujian secara parsial digunakan untuk melihat bagaimana pengaruh untuk setiap variabel independen terhadap variabel dependennya. Pengujian parsial dapat dilakukan dengan menggunakan uji $t$ student. Pengujian secara parsial dilakukan sebanyak $k$ kali tergantung dari banyaknya variabel prediktor yang di masukkan kedalam model. Adapun hipotesis pengujiannya adalah sebagai berikut:

$H_{0}: \beta_{k}=0$

$H_{1}: \beta_{k} \neq 0$

Statistik uji:

$t=\frac{\hat{\beta}_{k}}{\operatorname{Se}\left(\hat{\beta}_{k}\right)}$

Kriteria uji: Tolak $\mathrm{H}_{0}$ jika $\left|t_{\text {hitung }}\right|>t_{\text {tabel }}$, artinya koefisien regresi ke- $k$ berarti dalam model.

\subsection{Koefisien Determinasi}

Nilai dari koefisien determinasi digunakan untuk menjelaskan kesesuaian dari model yang dibuat. Nilai koefisien determinasi juga dapat menjelaskan variasi dari model, seberapa besar variasi penjelas dari variabel prediktor yang di masukkan kedalam model tersebut. Koefisien determinasi dapat dihitung dengan rumus sebagai berikut:

$$
R^{2}=\frac{\sum(\hat{Y}-\bar{Y})^{2}}{\sum\left(Y_{i}-\bar{Y}\right)^{2}}=\frac{J K R}{J K T}
$$

dimana:

JKR : Jumlah Kuadrat Regresi

JKT : Jumlah Kuadrat Total

\subsection{Variabel penelitian}

Variabel yang digunakan dalam penelitian ini adalah sebagai berikut:

$\mathrm{Y}=$ hasil produksi padi di Sulawesi Tengah (Ton)

$X_{1}=$ luas lahan $(\mathrm{Ha})$

$X_{2}=$ luas panen $(\mathrm{Ha})$

$X_{3}=$ produktivitas $(\mathrm{Ku} / \mathrm{Ha})$

Banyaknya kabupaten dan kota yang diteliti sebanyak 12 daerah, dan tahun penelitian yaitu 6 tahun dari tahun 2014-2020 [16].

\subsection{Uji Normalitas}

Pengujian normalitas residual pada metode Ordinary least square berguna untuk menguji nilai error dari data berdistribusi normal atau tidak [17]. Pengujian normalitas data dapat menggunakan KolmogorovSmirnov.

\section{Hipotesis:}

$H_{0}: F(\varepsilon)=F_{0}(\varepsilon)$ (error berdistribusi normal)

$H_{1}: F(\varepsilon) \neq F_{0}(\varepsilon)$ (error tidak berdistribusi normal)

Statistik Uji :

$D=\operatorname{Maksimum}\left|F(\varepsilon)-F_{0}(\varepsilon)\right|$

Dimana:

$F(e)$ : Nilai distribusi komulatif yang dihipotesiskan 
$F_{0}(e)$ : Nilai distrsibusi komulatif empiris dari data pengamatan

Kriteria uji : Tolak $\mathrm{H}_{0}$ jika $\mathrm{D}>D_{\text {tabel }}$, atau jika nilai p-value $<$ nilai alpha maka error berdtribusi normal.

\subsection{Uji Heteroskedastisitas}

Pengujian heteroskedastisitas digunakan untuk menguji apakah data yang digunakan memenuhi syarat varians error bersifat konstatn (homoskedastisitas) [18]. Pengujian asumsi terdapat atau tidaknya heteroskedastisitas dapat menggunakan pendekatan uji Breusch-Pagan. Pada hipotesis nol menyatakan bahwa varians dari error tidak berkaitan dengan variabel independen sedangkan hipotesis alternatif menyatakan bahwa variasn dari error merupakan fungsi parametrik dari variabel terikat [19].

Hipotesis:

$H_{0}: E\left(\boldsymbol{\varepsilon} \boldsymbol{\varepsilon}^{\prime}\right)=\sigma^{2} \mathbf{I} \quad$ (tidak terdapat pelanggaran asumsi heteroskedastisitas)

$H_{1}: E\left(\boldsymbol{\varepsilon} \boldsymbol{\varepsilon}^{\prime}\right) \neq \sigma^{2} \mathbf{I}$ (terdapat pelanggaran asumsi heteroskedastisitas)

Statistik uji:

$\mathrm{BP}=\frac{1}{2} f^{\prime} Z\left(Z^{\prime} Z\right)^{-1} Z^{\prime} f$

Dimana:

$f^{\prime}=\frac{e_{i}^{2}}{\widehat{\sigma}^{2}}-1$

$e_{i}:$ error pengamatan ke- $i$

$\hat{\sigma}^{2}$ : penaksir parameter

$\mathrm{Z}$ : matriks variabel independen

Kriteria uji: Tolak Hipotesis $\mathrm{H}_{0}$ jika nilai $\mathrm{BP} \geq \chi_{(k)}^{2}$ atau jika nilai $\mathrm{p}$-value < nilai alpha, maka artinya terdapat pelanggaran asumsi heteroskedastisitas.

\subsection{Uji Autokorelasi}

Pengujian autokorelasi dilkaukan untuk mengecek apakah terjadi pelanggaran error dari periode waktu yang berbeda saling berkorelasi. Untuk mengetahui ada atau tidaknya autokorelasi maka dapat dilakukan pengujian dengan uji Durbin Watson [20].

Hipotesis:

$H_{0}: \rho=0 \quad$ (tidak terdapat autokorelasi)

$H_{1}: \rho \neq 0 \quad$ (terdapat autokorelasi)

Statistik uji:

$d=\frac{\sum_{i=1}^{N} \sum_{t=1}^{T}\left(e_{i t}-e_{i t-1}\right)^{2}}{\sum_{i=1}^{N} \sum_{t=1}^{T} e_{i t}^{2}}$

Kriteria uji:

Pada pengujian durbin watson terdapat tiga kondisi keadaan yaitu:

- Kondisi pertama yaitu jika nilai $\mathrm{d}_{\text {hitung }}<\mathrm{d}_{\mathrm{L}}$ atau $\mathrm{d}_{\text {hitung }}>\left(4-\mathrm{d}_{\mathrm{L}}\right)$, maka $\mathrm{H}_{0}$ ditolak, sehingga terdapat autokorelasi

- Kondisi kedua yaitu jika nilai $d_{\text {hitung }}>d_{u}$ atau $d_{\text {hitung }}<4-d_{u}$, maka $H_{0}$ diterima, sehingga tidak terjadi autokorelasi

- Kondisi ketiga yaitu jika nilai $\mathrm{d}_{\mathrm{L}} \leq \mathrm{d}_{\text {hitung }} \leq \mathrm{d}_{\mathrm{u}}$ atau $\left(4-\mathrm{d}_{\mathrm{u}}\right) \leq \mathrm{d}_{\text {hitung }} \leq\left(4-\mathrm{d}_{\mathrm{L}}\right)$, maka kondisi ini tidak dapat disimpulkan ada atau tidaknya korelasi antar error dari periode waktu.

\subsection{Uji Multikolonieritas}

Pengujian asumsi multikolonieritas merupakan pengujian yang dilakukan untuk melihat bagaimana hubungan antar variabel independen dari suatu model regresi yang ada, hubungan yang di uji adalah apakah 
terjadi hubungan linier yang sempurna atau hampir sempurna. Pengujian multikolonieritas dapat menggunakan nilai Variance Inflation Factor (VIF) [21]. Nilai VIF dapat menunjukkan seberapa besar varians dari estimasi koefisien yang diakibatkan oleh multikolinearitas.

$V I F_{i}=\frac{1}{1-R_{i}{ }^{2}}$

Dimana:

$R_{i}^{2} \quad$ : nilai koefisien determinasi dari regresi variabel independen ke- $i$

\section{Kriteria uji:}

Jika nilai $V I F_{i}<10$, maka dapat disimpulkan bahwa tidak terdapat multikolonieritas, sedangkan jika nilai $V I F_{i} \geq 10$ maka dapat disimpulkan bahwa terdapat multikolinearitas.

\section{HASIL DAN PEMBAHASAN}

Hasil produksi padi di Sulawesi Tengah berdasarkan pembagian wilayah kabupaten dan kota dari tahun 2014 sampai dengan 2020 dengan menggunakan analisis regresi data panel dengan menggunakan Fixed Effect Model. Fixed Effect Model yang menggunakan pendekatan Least Square Dummy Variable. Berdasarkan hasil pengujian di dapatkan hasil taksiran untuk masing-masing parameter Fixed Effect Model sebagai berikut:

$$
\begin{aligned}
& \hat{Y}_{i t}=3,1904+1,0526 D_{2}+0,8126 D_{3}+0,9567 D_{4}+0,8210 D_{5} \\
& +0,8853 D_{6}+0,4716 D_{7}+1.3122 D_{8}+0,1076 D_{9}+0,8745 D_{10} \\
& +0,5799 D_{11}-0,4382 D_{12}+0,0572 D U M_{2015}-0,0628 D U M_{2016} \\
& -0,2998 D U M_{2017}+0,0618 D U M_{2018}-0,0420 D U M_{2019} \\
& -0,0295 D U M_{2020}+0,0639 X_{1 i t}+0,6764 X_{2 i t}+0,0030 X_{3 i t}
\end{aligned}
$$

Dari hasil taksiran parameter diatas, dapat dilihat bahwa nilai hubungan dari variabel luas lahan $\left(X_{1}\right)$, luas panen $\left(X_{2}\right)$ dan produktivitas $\left(X_{3}\right)$ bertanda positif sehingga variabel tersebut memiliki hubungan yang poositif terhadap hasil produksi padi di wilayah Sulawesi Tengah $(Y)$.

Ordinary least square memiliki empat asumsi klasik yang harus dipenuhi untuk menghasilkan model estimasi yang bersifat Best Linier Unbiased Estimator (BLUE). Jika salah satu dari asumsi tidak terpenuhi maka perlu dilakukan penanggulangan untuk asumsi yang terlanggar. Pengujian asumsi yang perlu di penuhi untuk metode ordinary least square adalah:

\section{a. Asumsi Normalitas}

Berdasarkan hasil analisis dengan menggunakan Uji kolmogorov-smirnov diperoleh :

nilai $p$-value $=0,0796$

jika nilai p-value dibandingkan dengan nilai alpha maka akan lebih besar dari nilai alpha sebesar $5 \%$. Sehingga dapat disimpulkan bahwa residual dari data mengikuti distribusi normal.

\section{b. Asumsi Heteroskedastisitas}

Berdasarkan hasil pengujian hetereskodestasitas dengan menggunakan pengujian Breusch-Pagan diperoleh :

nilai $p$-value $=3,039 \mathrm{e}-05$

jika nilai p-value artinya lebih kecil dari nilai alpha 5\%, maka dapat disimpulkan bahwa terdapat heteroskedastisitas.

Karena terdapat pelanggaran asumsi heteroskedastisitas maka dilakukan penanggulangan dengan menggunakan Newey-West Standard Error [22]. Jika terjadi pelanggaran asumsi heteoskedastisitas akan berdampak kepada penaksirnya. Pemaksir yang dihasilkan masih bersifat tak bias dan konsisten, tetapi tidak efisien yang mengakibatkan lebih lebarnya selang kepercayaan.

\section{c. Asumsi Autokorelasi}

Pengujian autokorelasi dilakukan dengan menggunakan Uji Durbin-Watson.

Didapatkan nilai durbin watson sebesar 2, 2198

nilai $\mathrm{dL}=1,53$ dan $\mathrm{dU}=1,73$.

Maka jika nilai durbin watson 2,2198 > nilai $\mathrm{dU}=1,73$ dan nilai durbin watson 2,2198 < 4-dU = 2,27 sehingga dapat disimpulkan tidak terdapat pelanggaran asumsi autokorelasi. 


\section{d. Asumsi Multikolonieritas}

Pengujian asumsi mulikolonieritas dapat dilakukan dengan menggunakan nilai Varian Inflation

Factor (VIF). Berdasarkan perhitungan masing-masing nilai VIF yaitu :

VIF antara $X_{1}$ dan $X_{2}=8,4271$

VIF antara $X_{1}$ dan $X_{3}=1,1031$

VIF antara $X_{2}$ dan $X_{3}=1,0859$

Hasil nilai VIF diatas menunjukkan bahwa tidak ada nilai VIF yang melebihi nilai 10 sehingga asumsi multikolonieritas sudah terpenuhi. Artinya tidak ada hubungan sempurna ataupun hampir sempuran antara varibel independen.

Dari empat asumsi yang harus dipenuhi, terdapat 1 asumsi yang terlanggar yaitu terdapatnya heteroskedastisitas, sehingga perlu dilakukan penanggulangan. Penanggulangan heteroskedastisitas dapat dilakukan dengan metode Newey-west estimator. Setelah dilakukan penanggulangan maka dihasilkan nilai taksiran yang tetap sama dengan menggunakan Fixed Effect Model hanya saja yang berbeda terdapat pada perubahan nilai standard error dan akan memberikan dampak terhadap nilai $t$ yang dihasilkan untuk model.

- Uji keberartian model secara keseluruhan atau uji simultan:

Uji keberartian model secara simultan dari hasil analisis menggunakan uji $\mathrm{F}$. Dari hasil analisis dengan menggunakan uji $\mathrm{F}$ diperoleh nilai $p$-value $=2,22 \mathrm{e}-16$ artinya lebih kecil dari nilai alpha 5\%, sehingga dapat disimpulkan bahwa model regresi yang di dihasilkan berarti.

\section{- Uji keberartian model secara parsial}

Hasil dari pengujian model secara parsial adalah sebagai berikut:

Tabel 1. Nilai $p$-value untuk pengujian model secara parsial

\begin{tabular}{|c|l|l|}
\hline Variabel & $\boldsymbol{p}$-value & kesimpulan \\
\hline$X_{1}$ & 0,0859 & Tidak berarti \\
\hline$X_{2}$ & $2,842 \mathrm{e}-10$ & berarti \\
\hline$X_{3}$ & 0,9929 & Tidak berarti \\
\hline
\end{tabular}

Pada Tabel 1 dapat dilihat bahwa variabel luas lahan dan produktivitas tidak berpengaruh terhadap hasil produksi padi di Sulawesi Tengah. Hal ini dikarenakan nilai $p$-value yang diperoleh lebih besar dari nilai alpha $5 \%$. Selanjutnya, variabel yang berpengaruh adalah variabel luas panen dimana nilai $p$-value yang diperoleh lebih kecil dari nilai alpha 5\%. Sehingga untuk model taksiran terbaik yang dapat digunakan unuk hasil produksi padi di Sulawesi Tengah adalah sebagai berikut:

$$
\begin{aligned}
& \hat{\mathrm{Y}}_{\mathrm{it}}=3,1904+1,0526 \mathrm{D}_{2}+0,8126 \mathrm{D}_{3}+0,9567 \mathrm{D}_{4}+0,8210 \mathrm{D}_{5} \\
& +0,8853 \mathrm{D}_{6}+0,4716 \mathrm{D}_{7}+1.3122 \mathrm{D}_{8}+0,1076 \mathrm{D}_{9}+0,8745 \mathrm{D}_{10} \\
& +0,5799 \mathrm{D}_{11}-0,4382 \mathrm{D}_{12}+0,0572 \mathrm{DUM}_{2015}-0,0628 \mathrm{DUM}_{2016} \\
& -0,2998 \mathrm{DUM}_{2017}+0,0618 \mathrm{DUM}_{2018}-0,0420 \mathrm{DUM}_{2019} \\
& -0,0295 \mathrm{DUM}_{2020}+0,6764 \mathrm{X}_{2 \mathrm{it}}
\end{aligned}
$$

Dari model FEM diatas dapat diketahui bahwa luas lahan panen memberikan hasil pengaruh yang positif terhadap hasil produksi padi di Sulawesi Tengah. Dari model diatas juga dapat diketahui bahwa dengan setiap kenaikan luas panen sebesar $1 \%$ maka akan membuat kenaikan terhadap hasil produksi padi sebesar 0,6764\%. Sehingga jika diluas panen meningkat maka produksi padi juga akan meningkat. Nilai koefisien variabel Dummy sebesar 0,9567 untuk Kabupaten Poso artinya jika menjaga semua faktor lain tetap konstan maka produksi padi di Kabupaten Poso akan lebih tinggi sekitar 0,9567\% jika dibandingkan dengan kabupaten Banggai Kepulauan (baseline). Sedangkan jika dilihat dari variabel Dummy untuk tahun 2018 yaitu 0,0618 berarti dengan menjaga semua faktor lain tetap konstan maka produksi padi di Sulawesi Tengah lebih tinggi sebesar 0,0618 jika dibandingakn tahun 2014 sebagia baseline.

\section{- Pengujian Koefisien Determinasi}

Nilai koefisien determinasi dapat digunkan untuk melihat seberapa besar varians yang diberikan oleh variabel independen terhadap variabel dependenya. Dari hasil analisis diperoleh nilai koefisien determinasi yang dari model taksiran terbaik sebesar 0,9815 . Artinya besarnya variasi dari variabel yang ada pada model dapat menjelaskan sebesar $98,15 \%$ dan sisanya $1,85 \%$ lagi dijelaskan oleh variabel lain yang tidak di masukkan kedalam model. 


\section{KESIMPULAN}

Berdasarkan hasil analisis data untuk pemodelan hasil produksi padi di Sulawesi tengan dengan enggunakan pendekatan model regresi data panel dengan Fixed effect effect maka dapat diperoleh dari tiga variabel independen yang dimasukkan dalam pengujian ternyata hanya ada satu variabel yang berpengarus secara parsial. Variabel yang berpengaruh terhadap model hasil produksi padi di Sulawesi Tengah adalah variabel luas panen $\left(X_{2}\right)$. Hubungan yang terbentuk pada model memperlihatkan hubungan yang positif dari tanda positif yang dihasilkan pada model FEM. Sehingga dapat disimpulkan dari model FEM tersebut setiap kenaikan luas panen sebesar $1 \%$ akan meningkatkan produksi padi sebesar $0,6764 \%$. dari hasil penelitian ini disimpulkan jika diharapkan ditahun yang akan datang produksi padi yang lebih besar maka yang harus di tingkatkan adalah luas panen untuk setiap daerah kabupaten dan kota di Provinsi Sulawesi Tengah. Nilai koefisien determinasi dari model sebesar 98.15\% artinya kemampuan variabel independen dalam menjelaskan varians dari variabel dependenya adalah $98.15 \%$ dan sisanya sebsar $1.85 \%$ dijelaskan oleh faktor lain yang tidak dimasukkan kedalam model.

\section{DAFTAR PUSTAKA}

[1] K. Pertanian, "Laporan tahunan badan ketahanan pangan tahun 2019," 2020.

[2] Badan Ketahanan Pangan, "Road Map Diversifikasi Pangan Lokal Sumber Karbohidrat Non Beras (2020-2024)," Kementeri. Pertan. Indones., pp. 1-49, 2020.

[3] Badan pusat statistik, "luas panen dan produksi padi di indonesia 2019," pp. 68-70, 1377.

[4] Kementerian Pertanian, Direktori Perkembangan Konsumsi Pangan. 2019.

[5] C. P. Dhakal, "Multiple Regression Model Fitted for Rice Production Forecasting in Nepal: A Case of Time Series Data," Nepal. J. Stat., vol. 2, no. June, pp. 89-98, 2018, doi: 10.3126/njs.v2i0.21157.

[6] C. Dhakal, "Single Regression to Forecast Rice Production: A Case of Time Period and Single Regression to Forecast Rice Production : A Case of Time Period and Harvest Area," no. August, 2018.

[7] O. Taofik Arowolo and M. Iwada Ekum, "Food Production Modelling Using Fixed Effect Panel Data for Nigeria and Other 14 West African Countries (1990-2013)," Am. J. Theor. Appl. Stat., vol. 5, no. 4, p. 208, 2016, doi: 10.11648/j.ajtas.20160504.17.

[8] N. Wulandari and Rahmadeni, "Analisis Faktor-Faktor yang Mempengaruhi Inflasi pada Kota Metropolitan di Indonesia dengan Menggunakan Analisis Data Panel," J. Sains Mat. dan Stat., vol. 3, no. 2, pp. 34-42, 2017.

[9] A. Fitrianto and N. F. K. Musakkal, "Panel Data Analysis for Sabah Construction Industries: Choosing the Best Model," Procedia Econ. Financ., vol. 35, no. October 2015, pp. 241-248, 2016, doi: 10.1016/s2212-5671(16)00030-7.

[10] D. T. Utari, T. Yuliana, and A. P. Hendradewa, "A Panel Data Analysis of Rice Production in Ngawi Regency, East Java," in Proceedings of the 2nd International Seminar on Science and Technology (ISSTEC), 2020, vol. 474, no. Isstec 2019, pp. 212 217, doi: 10.2991/assehr.k.201010.031.

[11] D. N. Gujarati and D. C. Porter, basic econometric. 2013.

[12] M. A. D. Muda, A. Affandi, and Y. K. Suprapto, "Icasess 2019," Forecast. Med. Purch. Budg. using Mult. Linear Regres. Method Case Study-For Ende Regency Heal. Off., p. 186, 2019.

[13] J. Mummolo, "Improving the Interpretation of Fixed Effects Regression Results*," vol. 6, no. 4, pp. 829-835, 2018, doi: 10.1017/psrm.2017.44.

[14] rizka zulfikar, "Estimation Model And Selection Method Of Panel Data Regression : An Overview Of Common Effect, Fixed Effect, And Random Effect Model," 2018, doi: 10.31227/osf.io/9qe2b.

[15] W. H. Greene, Econometric Analysis, vol. 03, no. 10. 2015.

[16] S. badan pusat, "BPS Prov Sulawesi Tengah.” https://sulteng.bps.go.id/statictable/2017/12/21/664/luas-areal-dan-produksitanaman-perkebunan-rakyat-menurut-jenis-komoditi-dan-kabupaten-kota-2016-.html.

[17] I. Muda, W. Maulana, H. S. Siregar, and N. Indra, "The analysis of effects of good corporate governance on earnings management in Indonesia with panel data approach," Iran. Econ. Rev., vol. 22, no. 2, pp. 599-625, 2018, doi: 10.22059/ier.2018.66169.

[18] O. L. Olvera and B. D. Zumbo, "Heteroskedasticity in Multiple Regression Analysis: What it is, How to Detect it and How to Solve it with Applications in R and SPSS [Heteroscedasticidad en análisis de regresión múltiple: qué es, cómo detectarlo y cómo resolverlo con aplicaciones en R y," Pract. Assessment, Res. Eval., vol. 24, no. 1, 2019.

[19] S. Informatic, T. F. Polytechnic, and C. Medicine, "Co mparis on ofdifferentte sts fordetecting he ter os c e d a s t i c i t y in d a t a s e t s," vol. XVIII, 2020.

[20] S. S. Uyanto, "Power comparisons of five most commonly used autocorrelation tests," Pakistan J. Stat. Oper. Res., vol. 16, no. 1, pp. 119-130, 2020, doi: 10.18187/PJSOR.V16I1.2691.

[21] N. A. M. R. Senaviratna and T. M. J. A. Cooray, "Diagnosing Multicollinearity of Logistic Regression Model," Asian J. Probab. Stat., vol. 5, no. 2, pp. 1-9, 2019, doi: 10.9734/ajpas/2019/v5i230132.

[22] Z. Nurlaila, M. Susilawati, D. Putu, and E. Nilakusmawati, "Standard Error Ketika Terjadi Heteroskedastisitas," E-Jurnal Mat., vol. 6, no. 1, pp. 7-14, 2017. 